\title{
Regional Factors in Boosting the Efficiency of Inviting Investments in Entrepreneurial Activity
}

\author{
Mansoor Maitah ${ }^{1}$, Almatova D.S. ${ }^{2}$, Kholnazar Amonov $^{3} \&$ Luboš Smutka $^{1}$ \\ ${ }^{1}$ Czech University of Life Sciences Prague, Prague 6, Czech Republic \\ ${ }^{2}$ Tashkent Financial Institute, Uzbekistan \\ ${ }^{3}$ Central Bohemia University, o.p.s., Czech Republic \\ Correspondence: Mansoor Maitah, Faculty of Economics and Management, Czech University of Life Sciences \\ Prague, Prague, ON., Kamýcká 129, 16521 Praha 6 - Suchdol, Czech Republic. Tel: 420-23438-2139. E-mail: \\ maitah@pef.czu.cz
}

Received: January 22, 2015

Accepted: March 13, 2015

Online Published: July 20, 2015

doi:10.5539/mas.v9n8p64

URL: http://dx.doi.org/10.5539/mas.v9n8p64

\begin{abstract}
This article is devoted to analyze the current condition of elaboration of regional investment projects at the present-day stage of economic reforms being led in Uzbekistan. Article sets forward proposals on working out prospective and present-day programs on inviting international financial institutions, foreign financial and insurance organizations and donor countries in order to implement with them investment projects of high importance for Uzbekistan. Practical recommendations on working out the mechanisms for implementation and efficiency assessment of investment projects, investment projects portfolio revolving to choose high priority investments were also suggested.
\end{abstract}

Keywords: small business, investment processes, entrepreneurial activity, regional economy, industry-specific and region-specific features of investments, investment attractiveness

\section{Introduction}

Overall review of investment processes development in Uzbekistan and economy of the regions, and inviting investments in entrepreneurial activity. Today enactment of a variety of regulations aimed at boosting investment climate attractiveness of the regions and intensifying investment processes is ensuring the growth of the country's investment potential and increase of foreign investments year after year, and thus, the growth of county's macroeconomic indicators, including, its gross domestic product volume. During the period of 2005-2013 in Uzbekistan, gross domestic product has increased at least 8.5 percent every year. Compared to the year of 2000, GDP volume grew by 2.9 -fold, industrial production increased by 2.6 -fold, volume of investments in the economy increased by 3.4 -fold, particularly, volume of foreign direct investments increased by 20 -fold. Small business sector, being a significant part of country's economy, is serving as a main source in supplying domestic market with necessary goods and services. Small business not only bridges some gaps in the economy, but also plays a vital role in diversification and development of the economy at stable paces. Uzbekistan is attaching great importance to building an institutional and market infrastructure which supports the development of small businesses and private enterprises. Since 2012, for the purpose of radical reduction of government intervention in the activity of business entities, 80 procedures related to various kind of permissions, as well as, licensing requirement of 15 types of entrepreneurship activities have been cancelled; also, number of financial statement submitting forms and periods of submitting them have been reduced by 1.5 -fold. In addition, new regulations introduced as of January 1, 2013, which canceled 65 statistical report forms and 6 tax report forms, and decreased the number of periods for submitting these reports by more than 2-fold.

\section{Literature Review}

Uzbekistan established an economic and legal base aimed at organizing investment processes and investment activity as per the market economy principles. But an investment climate, which promotes investment attracting in the economy of the regions, including, in small businesses, has not been fully created yet. This requires working out effective strategies aimed at boosting the volume of investments to be invited in the economy of the regions. 
In this view, development of investment activity of small businesses plays an important role in attaining key objectives directed to stable development of production potential of the regions' economy based on the priority directions of innovative renovation. Primary purpose of research activities in this topic is to study and determine the conditions and factors which opening the doors to development of investment activity of small enterprises in the present-day context, as well as, to determine the real prospects of investment cooperation between small and large enterprises.

International experience and theoretical and research conclusions confirm that entrepreneurial activity is the power that eliminate problems in the economy, and investment policy serves as its main source and factor. In turn, flexibility of production for market conditions, import substitution and export-orienteers of production is ensured by coordination of investment policy directions, fields, and sources. Rational investment policy increases labor and capital productivity, opens doors to satisfying the needs of consumers with high quality products.

\section{Method}

Our research studies indicate that after setting regional policy on small business development, often, it will be possible to get the results of implementation of this policy only after a long time, when it has been late to change something.

Therefore, we think that it is necessary to model various variants by means of economic and mathematical models in order to avoid negative consequences of made decisions.

Many models are built on a basis of reflecting small enterprises in the form of R. Stone's production function (Leontyev function):

$$
P(t)=\min \{F(t) / a, C(t) / b, L(t) / \theta\}
$$

where $\mathrm{P}(\mathrm{t})$ - production of goods and services by small enterprises (in physical volume);

$F(t)$ - fixed assets, $C(t)$ - current capital, $L(t)$ - labor resources;

$a, b, \theta$ - expenditure rate of related production factors per production unit $P(t)$ (soums);

$t$ - time (simulation step).

Reflecting a small enterprise in this way is convenient; moreover, production function also includes the employment as its structural component. But, in practice, it is impossible to build models for every established enterprise. In modeling the regional level decision making, taking regional small business sector as a single object makes good results. For this, it is necessary to use simulation modeling methods.

As a typical problem to be solved in process of supporting small businesses in a region, we can take the issue of financing some small enterprises chosen in a particular sector in a context of limited financial resources. In general, this model looks like as follows:

$$
\begin{gathered}
I N V=\sum_{i=1}^{n} \operatorname{inv}_{i} \\
P R=\sum_{i=1}^{n} \operatorname{rev}_{i}-I N R-N R \\
n=q+k+l+\ldots+m, \text { here }
\end{gathered}
$$

All investments are directed to financing small enterprises (equation 1). Profits from investments (equation 2) equals to the amount of money resources returned from each enterprise, minus invested investments, minus non-return of investments. Finally, regional investment policy (equation 3) is determined by allocating the number of enterprises for per investment direction. If an average number of employees of the enterprises in each investment direction is known, we can assess an additional labor market capacity emerging as a result of implementation of programs on supporting small businesses.

$$
\operatorname{Tr}=\sum_{j=1}^{q} t r_{j}+\sum_{j=1}^{k} t r_{j}+\ldots+\sum_{j=1}^{m} t r_{j}
$$

The modeling principles that reflected by the 1-4 equations indicated above were used in modeling the results of various region-wide measures taken to develop small business sector. The first model is a simulation model for the development of tourism sector in the regions of Uzbekistan.

Main elements constituting the tourism sector are the following systems: 
Accommodation system - major part of this system is, usually, consisted of hotels, and this complex also includes some small family passionate and rented private houses;

Catering system- it includes big restaurants, small cafeterias, fast food points (tents), retail stores selling ice-cream, bakery and other products;

Transportation system - presently, private sector is dominating in this system, and they are providing passenger transportation services by automobiles, minibuses, and even by large buses;

Entertainment services system - small artistic troupes, attractions, private art galleries, museums play a big role in this system;

Retail sales system - in this system, retails sales are run mostly by small enterprises and private entrepreneurs in majority of the regions;

Souvenirs complex - it includes folk crafts and souvenir goods producing enterprises. Services, such as laundry, dry cleaning etc. which don't directly relate to tourism, but make profit from it, are modeled separately.

\section{Results and Discussion}

During this research studies, we determined the correlation between the indicators reflecting the investment and economic activity results of an enterprise.

Regression equation is statistically important in our studies. Because determination coefficient has $45.6 \%$ value (table 1), and it reflects a close relationship between dependent variables (investments) and independent variables (profit, average number of workers, arable land areas, production expenditures, fixed assets):

$$
\mathrm{y}=2169.7+1.8 \mathrm{X} 3+55.1 \mathrm{X} 2+0.04 \mathrm{X} 6
$$

Parameters of regression equation show a direct proportional relationship of production factors which lead to growth of investments.

As volume of investments per farm business increases, amount of workforce wages and main indicators of production in an enterprise also will increase.

One of the important indicators to be used in the assessment of investments efficiency is a recovery of production costs. In addition, as we study investment attractiveness of agricultural enterprises, we determined that several production indicators have a great influence on the activity of enterprises.

We determined that area of agricultural lands, value of material current assets per hectare, number of workers per 100 hectares of agricultural land, amount of average yearly salary of workers have an influence on productivity of a small business's activity. Increase of agricultural land areas at all types agricultural enterprises has a positive effect on productivity of agricultural business, but this growth rate is not the same at all enterprises. As land areas increase by 100 ha, recovery of production costs in farms increases by 0.01 thousand uzbek soums. We can see that in a regression equation and coefficient of correlation. Regression equation for livestock farming units looks like as follows: $\mathrm{Y}=0.563+0.0001 \mathrm{x}$, linear coefficient value $(\mathrm{R}=0.492)$, correlation ratio is moderate. Regression equation for arable farming units is $\mathrm{V}=0.920+0.0001 \mathrm{x}$, the linear coefficient value $(\mathrm{R}=0.552)$, and correlation ratio is moderate.

When we studied the dependency of recovery amount of production costs on the number of workers per ha land area, it is determined that if the number of workers per 100 ha land area increases by 1 worker, recovery of production costs increases by 0.208 thousand uzbek soums. And the regression equation for this looks like as follows:

$\mathrm{y}=0.180+0.208 \mathrm{x}$ and $\mathrm{R}=0.844$ (correlation ratio is high).

Table 1. Multifactorial correlation and regression analyses of the dependency of investments on several selected indicators

\begin{tabular}{lllll}
\hline Parameters & Value of parameters & Standard error & Statistical error & Level of reliance \\
\hline Free coefficient & 2169.57 & 1022.13 & 2.122 & 0.0348 \\
X1-X2 & 1.7863 & 0.3683 & 4.85 & 0 \\
X3-X1 & 55.067 & 6.192 & 8.894 & 0 \\
X4-X5 & 0.037 & 0.120 & 0.311 & 0.05 \\
\hline
\end{tabular}

Source: own calculation. 
Determination coefficient $(D)=45.65 \%$. Explanations of reference characters:

Y1 - investments, mln uzbek soums; X1 - fixed assets, mln uzbek soums; X2 - average yearly number of workers, quantity; X3 - planted acres, ha; X4 - production costs, mln uzbek soums; X5- profits, mln uzbek soums.

Correlation ratio between recovery of costs and investments is high $\mathrm{R}=0.855$ and the regression equation will be as follows:

$$
\mathrm{y}=0.231+0.217 \mathrm{x}
$$

If volume of investments per 100 ha land areas increase by thousand uzbek soums, recovery of production costs increases by 0.237 uzbek soums. In the process of this research studies, we studied the investment inviting processes in entrepreneurial activity in a region, and also discovered several aspects of labor market by analyzing the distribution of employment level. Thus, small business is a complicated social and economic institution, and it should be studied at a full scale. For this purpose, we will build an integral indicator that reflects a development level of entrepreneurship in the regions.

The indicators reflecting the development level of small business in the regions serve as a data base to be used in building this integral indicator.

- $\quad$ Number of small enterprises registered in a region (SE);

- Employment of population in small business sector (EP). This index, at the same time, includes three indicators, accounting of which is maintained at the state statistics: number of workers in SE, number of workers having a second job in SE, and number of workers employed in SE on a contract basis;

- Volume of production (goods and services) produced by SE (Pr);

- Volume of investments in small business (In).

We assume that all indicators have equal influence on the development level of small business in a region, and thus, these indicators will be included into integral indicator with the assumption that all of these indicators carry an equal weight. The formula for calculation of the integral indicator that reflects the development level of small business in the region will look like as follows:

$$
\begin{aligned}
I_{I^{j} \text { dev }}= & \left.\frac{S E_{j}}{\max S E}+\frac{E P_{j}}{\max E P}+\frac{\operatorname{Pr}_{j}}{\max \operatorname{Pr}}+\frac{I n_{j}}{\max I n}\right) / 4= \\
= & \left(S E_{j}+E P_{j}+\operatorname{Pr}_{j}+I n_{j}\right) / 4,
\end{aligned}
$$

here $I^{\text {SBdev }}-\quad$ an integral indicator reflecting a development level of entrepreneurship in the $j$ region, $1<j \leq 85$; $\overline{S E}_{j}, E P_{j}, \operatorname{Pr}_{j}, I n_{j}$ - normed values of the indicators.

Table 6 shows the calculation results about regions and leaders in regional development of small business. Tashkent city has an absolute leadership in small business development level, and its integral indicator value is 0.863. But while Tashkent city had a maximal value in all four indicators in $2012\left(I_{\text {Tash_2012 }}^{S E}=1\right)$, now Tashkent region has been ahead of Tashkent city in production turnover $\left(I_{\text {Tash.reg }}^{S E}=0,368\right)$.

In the meantime, Tashkent region also secured the second place in the overall ranking, outstripping Andijan region $\left(I^{A n d}=0.363\right)$.

As was previous periods, Tashkent city is still ahead of the other regions in the ranking by the value of integral indicator that reflect a development level of small business, but the value of this difference has been decreased a bit, up to 0,495 , since 2012 (that was 0.602 in 2012).

The top ten of the ranking was secured by the regions in which big cities are located. This situation is explained by the following facts: firstly, there is usually huge demand for goods and services produced in big cities, and 
this creates favorable conditions for the development of small business sector; secondly, an infrastructure for supporting small business functions more efficiently in city areas. Now we discuss how much small business sector contributes to the development of the regions and we will compare the regions by the volume of this contribution. For this purpose, we will use the same method which we already used to analyze development level of small businesses in the regions when we built the integral indicator. We will use the following indicators to build an integral indicator that indicates the contribution of small enterprises to development of the regions:

- number of small enterprises per 1000 population of a region;

- share of employees employed in small business sector within the total number of employed population in a region;

- share of small business sector turnover within the total turnover of enterprises in a region;

- share of investments in fixed assets of small enterprises within the total volume of investments invested in a region.

- The formula for calculation of the integral indicator that reflects the contribution of small enterprises to development of a region will look like the one we saw above:

$$
\begin{aligned}
& I_{j}^{\text {SBcont }}=\left(\frac{\text { SBnum }_{j}}{\max S B n u m}+\frac{\Delta \text { ShEmp }_{j}}{\max \Delta \text { ShEmp }}+\frac{\Delta \text { SBturn }_{j}}{\max \Delta \text { SBturn }}+\frac{\Delta \text { SBin }_{j}}{\max \Delta \text { SBin }}\right) / 4= \\
& =\left(\operatorname{SBnum}_{j}+\bar{\Delta} \operatorname{ShEmp}_{j}+\bar{\Delta} \overline{\operatorname{SBturn}}_{j}+\bar{\Delta} \operatorname{SBin}_{j}\right) / 4,
\end{aligned}
$$

where $I^{S B c o n t}-\quad$ an integral indicator reflecting the contribution of small businesses for development of the $j$ region, $1<j \leq 85$;

SBnum $_{j}+\bar{\Delta} \operatorname{ShEmp}_{j}+\bar{\Delta} \overline{\operatorname{SBturn}}_{j}+\bar{\Delta} \operatorname{SBin}_{j}$ - changed (normed) values of the indicators. Contribution of small businesses in Uzbekistan to the economic growth of the country in 2007 was as follows: at average, the number of small enterprises per 1000 population was 12.9 , and $51.3 \%$ of able-bodied population employed in small business sector, turnover of small business sector made up $31 \%$ of the total volume of the country's turnover, but investments in small business sector made up only $3,9 \%$.

Table 2. Integral indicators showing the development level of small business sector in the regions and the

\begin{tabular}{|c|c|c|c|c|c|c|}
\hline \multirow{3}{*}{$\begin{array}{l}\text { Territories and } \\
\text { regions }\end{array}$} & \multicolumn{6}{|c|}{ Year of 2012} \\
\hline & \multicolumn{3}{|c|}{$\begin{array}{c}\text { Development level of entrepreneurial } \\
\text { activity in a region }\end{array}$} & \multicolumn{3}{|c|}{$\begin{array}{c}\text { Contribution of small businesses to } \\
\text { development of a region }\end{array}$} \\
\hline & $I^{S M B d e v}$ & place & $\begin{array}{l}\text { Place in the } \\
\text { territory }\end{array}$ & $I^{S M B d e v}$ & place & $\begin{array}{l}\text { Place in the } \\
\text { territory }\end{array}$ \\
\hline Tashkent territory & 0.956 & 1 & - & 0.742 & 1 & - \\
\hline Fergana territory & 0.598 & 2 & - & 0.628 & 2 & - \\
\hline Zarafshan territory & 0.371 & 5 & - & 0.603 & 3 & \\
\hline Southern territory & 0.390 & 3 & - & 0.602 & 4 & - \\
\hline Mirzachul territory & 0.389 & 4 & - & 0.596 & 5 & - \\
\hline $\begin{array}{l}\text { Lower Amudarya } \\
\text { territory }\end{array}$ & 0.234 & 6 & - & 0.427 & 6 & - \\
\hline Tashkent city & 0.863 & 1 & 1 & 0.588 & 2 & 1 \\
\hline Andijan region & 0.364 & 3 & 1 & 0.622 & 1 & 1 \\
\hline Navoiy region & 0.338 & 4 & 2 & 0.329 & 7 & 2 \\
\hline Tashkent region & 0.284 & 2 & 2 & 0.321 & 8 & 2 \\
\hline
\end{tabular}
contribution of small businesses to development of the regions 


\begin{tabular}{|c|c|c|c|c|c|c|}
\hline Fergana region & 0.207 & 6 & 3 & 0.305 & 9 & 2 \\
\hline Namangan region & 0.369 & 5 & 2 & 0.252 & 11 & 3 \\
\hline Samarkand region & 0.095 & 7 & 3 & 0.317 & 10 & 3 \\
\hline Bukhara region & 0.144 & 8 & 1 & 0.359 & 3 & 1 \\
\hline $\begin{array}{l}\text { Kashkadarya } \\
\text { region }\end{array}$ & 0.211 & 9 & 1 & 0.358 & 4 & 1 \\
\hline Khorezm region & 0.168 & 10 & 1 & 0.251 & 12 & 1 \\
\hline $\begin{array}{l}\text { Surkhandarya } \\
\text { region }\end{array}$ & 0.095 & 11 & 2 & 0.250 & 13 & 2 \\
\hline Djizzakh region & 0.144 & 12 & 2 & 0.357 & 5 & 1 \\
\hline Sirdarya region & 0.211 & 13 & 1 & 0.356 & 6 & 2 \\
\hline $\begin{array}{l}\text { Karakalpak } \\
\text { Republic }\end{array}$ & 0.168 & 14 & 2 & 0.249 & 14 & 2 \\
\hline
\end{tabular}

Source: own calculation

Table 2 shows the ranking of the regions made based on calculations of integral indicator that describes contribution of small enterprises to economic development of the regions in 2007 and 2012: The secured places of the regions in the ranking in 2012 coincide with the ones secured by the regions in 2007. Tashkent and Fergana territories led the ranking in contribution of small businesses to development of the regions. $I_{\text {Tash }}^{\text {SBcont }}=$ 0.742 (0.659 in 2007), this value came from as follows: the number of small enterprises per 1000 population of Tashkent territory was 17.7 (14.4 in 2007), and this indicator for Tashkent city was 19.5; percentage of able-bodied population employed in these small enterprises was $74.7 \%$ (70,3\% in Tashkent city); turnover of small enterprises made up $52.2 \%$ of the total volume of territory's turnover ( $48,1 \%$ in Tashkent region); only $12 \%$ of the total investments invested in fixed assets was directed to small enterprises (14\% in Tashkent region). Zarafshan territory secured one of the leading places in the ranking in contribution (share within the total volume of production turnover) of small enterprises to the production in the territory $\left(I^{\Delta \text { Zaraf }}=0.603\right)$.

\section{Discussion}

It is necessary to define an investment policy of small enterprises in the regions based on the following principles:

$>$ Directing investments primarily to economic sectors that have a competitive advantage (competitive advantage in production costs, competitive advantage coming from production of rare and not readily available goods which have a high demand in domestic and world markets).

Implementing structural reforms in the economic complexes of the regions and economic sectors.

> Directing investments goal-oriented. Today investments should be directed to restructuration of the regional economies, production in real sector of the economy, building a market infrastructure.

$>$ Priority of investing in innovative technologies. This enables to boost profits, improve the conditions of extended reproduction, rebuild the structure of regional enterprises on the basis of innovative industry, as well as, to enhance competitiveness of produced goods.

Investing in human capital. Because it is impossible to create and use modern innovative technologies without highly skilled workforce.

> Market relations require development of market infrastructure (banks, sales and hotel complexes, exchange houses etc.).

Studies of international experience indicate that the most important factors that open doors to cooperation between large and small enterprises in the context of modern innovative economy are as follows:

- High level of specialization of small business enterprises, and their active innovative activity (because competition in each market segment forces them to enhance their activeness of innovative activity); 
- $\quad$ endeavor of business entities to minimize transactional costs and extend market prospects by building a flexible technological and sales chain;

- $\quad$ endeavor of big firms to introduce innovative technologies in their activity by means of small innovator firms;

- $\quad$ existence of special institutions cooperating and intermediating in innovations, as well as, existence of efficient financial credit technologies that support venture entrepreneurship;

- $\quad$ existence of goal-oriented state measures that stimulate stable relations of big firms with small enterprises in production and cooperation;

- $\quad$ efficient distribution of authority and resources among central, regional and local government bodies for supporting small business sector.

These principles should be reflected on the new strategy of the state (above all, on the related goal-oriented programs, regulatory measures in budgetary and tax matters) for supporting small business sector. In our opinion, it is necessary to take the following countrywide measures to boost the efficiency of using domestic resources for financing regional investment projects:

- implementation of investment projects where return of capital investments is fast, reduction of energy and material consumption in industrial production;

- stimulation of private capital participation in financing the construction of industrial facilities, supporting the emergence and development of small enterprises;

- intensification of establishment of industrial enterprises, radical reduction of the number of facilities in the economy, construction of which is incomplete;

- assessment of industrial enterprises' performance, calculation of profitability level, dynamically analyzing economic indicators;

- provision of more free access to data and information related to investment activity, monitoring development of national production;

- promoting economic entities to carry out their activities without restrictions for etc.

As a final conclusion, it is important to point out that we can solve many issues associated with building a developed market economy in Uzbekistan by boosting investment potential of the regions and efficiently implementing investment projects.

\section{References}

Abrams, S. (2002). A Practical Approach to the International Valuation and Capital Allocation Puzzle. Salomon Smith Barney.

Bruner, R., et al. (2002). Introduction to 'Valuation in Emerging Markets. Emerging Markets Review, 3.

Colin, J. (1998). State Keeps a Tight Rein: Market Reform in Uzbekistan. The Banker, 14(8), 47-50.

Estrada J. (2007). Discount rates in emerging markets: four models and an application. Journal of Applied Corporate Finance, 19, 72-78.

Estrada, J. (2002). Systematic risk in emerging markets: the D-CAPM. Emerging Markets Review, 3, 365-379.

James, M., \& Koller T. (2000). Valuation in emerging markets. Corporate Finance, 4, 78-85.

Koller T., \& Murrin, J. (2000). Valuation: Measuring and Managing the Value of Companies (3rd ed.). New York: John Wiley \& Sons.

Luehrman, T. (1997). General manager's guide to valuation. Harvard Business Review.

Luehrman, T. (2009). Business valuation and the cost of capital. Harvard business school publishing, Boston, 9-210-037.

Peimani, H. (2009). Conflict and Security in Central Asia and Caucasus. Santa Barbara, Calif.

PRICEWATERHOUSECOOPERS. (2013). Guide to doing business and investing in Uzbekistan. Retrieved from www.pwc.com/uz

Tsamenyi, M., \& Tauringana, V. (2004). Capital budgeting and budgeting practices of foreign operations in Uzbekistan: an exploratory study. International Journal of Strategic Cost Management. Spring, 20-36.

UNs Economic and Social Commission for Asia and Pacific. (2003). Managing globalization in selected 
countries with economies in transition.ST-ESCAP/2274. United Nations. New York.

Yescombe, E. (2007). Public-Private partnerships. Principles of Policy and Finance. Published by Elsevier ltd. UK.

\section{Copyrights}

Copyright for this article is retained by the author(s), with first publication rights granted to the journal.

This is an open-access article distributed under the terms and conditions of the Creative Commons Attribution license (http://creativecommons.org/licenses/by/3.0/). 